Limnol. Rev. (2014) 14,3: 111-119

\title{
Roosting colony of cormorants (Phalacrocorax carbo sinensis L.) as a source of nutrients for the lake
}

\author{
Piotr Klimaszyk $^{1^{*}}$, Tomasz Joniak ${ }^{1}$, Piotr Rzymski ${ }^{2}$ \\ ${ }^{1}$ Department of Water Protection, A. Mickiewicz University, Umultowska 89, 61-614 Poznań, Poland, *e-mail: pklim@amu.edu.pl \\ (corresponding author) \\ ${ }^{2}$ Department of Biology and Environmental Protection, University of Medical Sciences, Rokietnicka 8, 60-806 Poznań, Poland
}

\begin{abstract}
Since 2005, great cormorants have been observed on the Lake Góreckie (Wielkopolski National Park) shoreline. The population of these birds occurring within the lake has gradually increased. In autumn 2008, more than 100 individuals were observed. In the period 2009-2012 the number of birds occupying the island periodically exceeded 250 individuals. So far, there is no breeding colony of great cormorants, but the birds have established a roosting colony on the island. In the period 2009-2012 we conducted research on the impact of the colony of great cormorants on the accumulation of nitrogen, phosphorus and other elements in soils beneath the colony and transfer of chemical elements from the colony to a nearby freshwater ecosystem. Our results show that a relatively small and recent colony of great cormorants can significantly affect the chemistry of soil. Compared to a control, the soil beneath the colony was characterized by statistically higher concentrations of nitrogen and phosphorus. A significant accumulation of nutrients was observed in the topsoil zone (to a depth of about $20 \mathrm{~cm}$ ). Enrichment of soil in chemical elements has resulted in their further transport to a nearby lake. Compared to the control, the groundwater and surface runoff from the colony area revealed several-fold higher concentrations of nitrogen and phosphorus. The maximum abundance of cormorants in the roosting colony was reflected in the elevated concentrations of nitrogen and phosphorus in the littoral water near the colony. Our study demonstrates that the roosting colony of great cormorants can play a significant role in accelerating the eutrophication of surface waters.
\end{abstract}

Key words: great cormorant, nitrogen, phosphorus, surface runoff, groundwater

\section{Introduction}

Since the 1980s a rapid growth in the population of the great cormorant (Phalacrocorax carbo sinensis L.) has been observed around Europe (Saks 2012; van Eerden et al. 2012). The reasons explaining this phenomenon include: i) the protection of the great cormorant in numerous countries; ii) increase in food availability due to cultural eutrophication; iii) a global increase in both the inland temperature and that of coastal marine waters (van Erden and Gregersen 1995; White et al. 2011). In Poland, since the beginning of the 20th century, the number of great cormorants has increased from only 15 to over 25,000 breeding pairs (Bzoma et al. 2003). The growing population of these birds has raised concerns as to the consequences of their presence in the environment. The greatest threats posed by great cormorants include their potential impact on fish fauna and fishery. However, it is worth noticing that waterfowls such as great cormorants are a very important intermediate link in food webs and a factor that facilitates the dislocation of matter between aquatic and terrestrial ecosystems (Marion et al. 1994). Great cormorants may have an impact on the process of eutrophication of water reservoirs either positively or negatively. When they feed in water but excrete on land, they can remove loads of nutrients (together with fish) from the water ecosystem and delay the process of eutrophication. However, while great cormorants prey on fish on many aquatic ecosystems simultaneously, within a radius of $30 \mathrm{~km}$ from the colony (Cramp and Simmons 1977), they deposit their droppings on a relatively small area under the colony (Kameda et al. 2006) and near the lake. In turn, increased concentrations of nitrogen $(\mathrm{N})$, phosphorus (P) and other chemical elements provided by the birds within the area of the colony may then be transferred together with groundwater or surface runoff to near- 
by lakes, thereby inducing significant chemical and biological changes (Gere and Andrikovics 1992, Nakamura et al. 2010; Klimaszyk 2012; Klimaszyk et al. 2014). Moreover, microbial pollution of littoral zones can be observed within the area of bird colonies (Klimaszyk 2012, Klimaszyk and Rzymski 2013a).

Since 2005, we have observed the appearance of great cormorants on the shores of Lake Góreckie. The birds occupy Castle Island located in the central part of the lake. In recent years the number of cormorants has periodically reached 250. Lake Góreckie is located in the Wielkopolski National Park. Despite the strict protection of its area, the chemical and biological quality of the water in the lake is unsatisfactory and is gradually deteriorating (Sobczyński and Joniak 2009).

In this paper the hypothesis has been put forward that the great cormorants constituting the lakeshore roosting colony deposit considerable quantities of nutrients and other chemical substances onto the soil beneath the colony. We have studied the accumulation of nutrients in the soil and evaluated whether surface runoff and groundwater play any relevant role in the transfer of nutrients from the colony area to the lake. Our study demonstrates that the roosting colony of great cormorants can have a significant impact on the quality of water and contribute to the eutrophication of the lake, in spite of its being situated within a protected area with limited human pressure.

\section{Material and Methods}

The Lake

Lake Góreckie is located in Wielkopolski National Park (North-West Poland) with a latitude and longitude of $52^{\circ} 26.7^{\prime} \mathrm{N}$ and $16^{\circ} 79.4^{\prime} \mathrm{E}$, respectively. It is a postglacial ribbon lake with a relatively large area of 103 ha and great depth (average of $9 \mathrm{~m}$, maximum $17 \mathrm{~m}$ ). It has no outflows and is almost entirely surrounded by hilly forested banks. The lake is naturally divided into two sub-basins: a deeper southern one and a shallower (maximum depth of $10 \mathrm{~m}$ ) northwestern one. The catchment area of the lake is over 650 ha and about $70 \%$ of it is covered by forest while the remaining $30 \%$ consists of agricultural fields and rural areas. Lake Góreckie has been classified into the 2nd category of susceptibility to degradation (Szyper and Gołdyn 2002). It reveals some signs of advanced degradation (Sobczyński and Joniak 2009). The main reason for this is that for many years the lake received untreated waste from a nearby sanatorium. Despite the waste inflows being cut off at the end of the 1990s, the lake remains eutrophic (Szyper and Gołdyn 2002). Intensive phytoplankton blooms and deoxygenation of meta and hypolimnion are observed during every vegetative season. In order to protect the lake from further degradation a number of treatments aimed at reducing human impact within the catchment area have been implemented including a decrease in fertilizer use and improvement in sewage management. Other restorative approaches have also been adopted such as aeration of the hypolimnion zone, $\mathrm{P}$ inactivation by ferric coagulant and the removal of 3 tons of fish (Sobczyński and Joniak 2013).

\section{The roosting colony of great cormorants}

Since 2005, great cormorants have been observed on the lake shoreline. Due to insignificant human pressure, the birds generally occupy Castle Island located in the middle of the lake. Initially only single individuals were observed although the population of great cormorants occurring within the lake area has gradually increased. In autumn 2008, more than 100 individuals were observed. In the period 2009-2012 the number of birds occupying the island periodically exceeded 250 individuals (October 2011). Great cormorants were distributed unevenly on the island and concentrated on its northern shore. They roost on edge alder (Alnus glutinosa) trees. During dry periods, tree leaves were covered by bird guano; however, significant damage to trees was not found. Herbs under the roost were as dense as at a control station but included numerous specimens of nitrophilous nettle (Urtica dioica). The number of individuals forming the roosting colony varied over seasons. With the exception of winter months (December-March), great cormorants almost always occupied the area of the island but the maximum number of birds was observed in the summer and autumn months. So far, no breeding colony has been formed but the birds have managed to establish a roosting colony.

\section{Sampling sites and sample collection}

The main investigations were conducted between 2009 and 2012. Samples were taken in the vegetative season from April to October from sites located beneath the roosting colony and from control sites situated on the lake shore (Fig. 1). Sites were comparable according to soils, morphology and vegetation.

Soil samples were taken bimonthly at three genetic soil horizons: organic - the ectohumic soil horizon, at a depth of $0-5 \mathrm{~cm}$; the eluvial horizon at a 


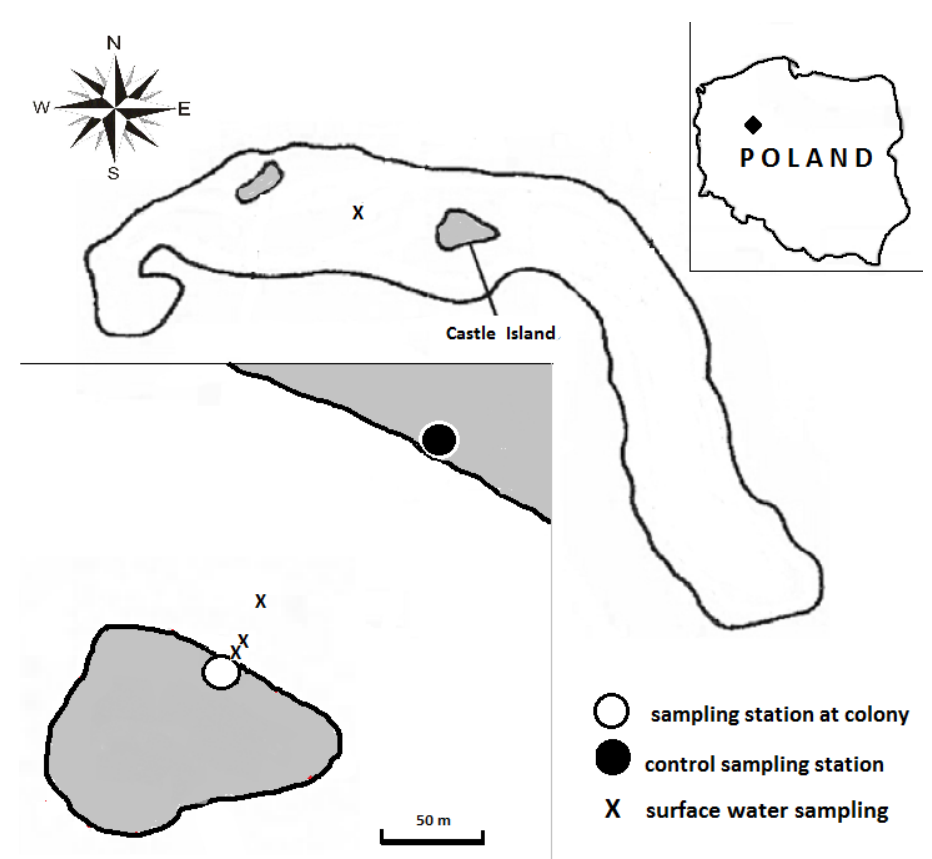

Fig. 1. Lake Góreckie with the indication of the roosting colony and location of sampling stations

depth of $5-20 \mathrm{~cm}$; the mineral horizon, at a depth of $>20 \mathrm{~cm}$. Air-dried soil samples were sieved using a $1 \mathrm{~mm}$ sieve to separate gravel (particle size $>1 \mathrm{~mm}$ ) and non-soil components. Surface runoff water samples were taken using samplers made of PVC gutters ( $3 \mathrm{~m}$ long and $0.15 \mathrm{~m}$ wide) and sealed plastic collectors buried at the lower end at an angle that prevented the direct inflow of rainwater. The gutters were placed under the forest litter and covered with a 0.25 $\mathrm{mm}$ mesh. Runoff water was collected after each precipitation event and during melting of the snowpack. Water samples from the littoral zone of Lake Góreckie were taken: i) at the edge of the island; ii) $10 \mathrm{~m}$ from the shore; iii) $50 \mathrm{~m}$ from the shore, all immediately after heavy rainfall. Samples of shallow groundwater were collected bimonthly from piezometers installed near the lake adjacent to the surface runoff samplers. Collected groundwater samples were filtered through a cellulose membrane GF-C.

\section{Analyses and calculations}

Electric conductivity and $\mathrm{pH}$ of water were measured in the field using a YSI 556 Multiparameter Instrument. In the collected samples of water the following parameters were analysed in the laboratory: ammonium ( $\mathrm{N}-\mathrm{NH}_{4}^{+}$, using the Nessler method), nitrites ( $\mathrm{NO}_{2}^{-}$, using the sulphonic acid method), nitrates $\left(\mathrm{N}_{-} \mathrm{NO}_{3}^{-}\right.$, using the sodium salicylate method), organic nitrogen $\left(\mathrm{N}_{\mathrm{org}}\right.$, using the Kjeldahl method), and orthophosphates (TRP, using the molybdate method) (APHA 2005). In soil samples, total Kjeldahl nitrogen $\left(\mathrm{N}_{\mathrm{tK}}\right)$ was determined using the Kjeldahl method (van Reeuwiijk 2002), nitrates $\left(\mathrm{N}_{\mathrm{NO} 3}\right)$ were determined colorimetrically after extraction in 0.03 mol $\mathrm{CH}_{3} \mathrm{COOH} \mathrm{dm}{ }^{-3}$, ammonium ions $\left(\mathrm{N}_{\mathrm{NH} 4}\right)$ were determined colorimetrically using Nessler's method, and $\mathrm{N}_{\mathrm{NO} 3}$ was determined using phenoldisulphonic acid (Prince 1995). Soil total phosphorus (TP) was determined at $850 \mathrm{~nm}$ using a Shimadzu UV-1610 spectrophotometer (molybdate method) after the samples were burned at $550^{\circ} \mathrm{C}$ and mineralized in $\mathrm{HNO}_{3}$ and $\mathrm{H}_{2} \mathrm{SO}_{4}$ (Sobczyński and Joniak 2009).

Statistical analyses were determined using Statistica 8.0 (StatSoft, USA). Gaussian distribution was tested with the Shapiro-Wilk's test and if the data did meet this assumption, evaluation of differences between the studied sites was assessed using the TStudent test while correlations were defined using the Pearson coefficient. If the data did not meet the Gaussian distribution assumption we used the MannWhitney $\mathrm{U}$ test. In all statistical analyses, a $p$ value of $<0.05$ was considered as statistically significant. 


\section{Results}

Loads of nutrients delivered by great cormorants versus loads from other sources

Without accurate data on the density of the colony, with the dynamically changing number of birds it is impossible to estimate the annual load of nutrients supplied by them. Therefore, we present a comparison of the daily loads imported by great cormorants at the maximum observed abundance, with daily inflow of nutrients from other sources.

According to Szyper and Gołdyn (2002) the annual load of nutrients inflowing to Lake Góreckie from diffused and dispersed sources is $9884 \mathrm{~kg}$ and $373 \mathrm{~kg}$ of $\mathrm{N}$ and $\mathrm{P}$, respectively. Thus, the daily load of nutrients is approximately $27 \mathrm{~kg}$ of $\mathrm{N}$ and $1 \mathrm{~kg}$ of P. Assuming from Marion et al. (1994) that one cormorant spent (roosted) 20 hours at the lake daily and produced $27 \mathrm{~g}$ of faeces (dry weight) containing 0.89 $\mathrm{g}$ of $\mathrm{N}$ and $3.86 \mathrm{~g}$ of $\mathrm{P}$, the maximal daily load of nutrients delivered by great cormorants to the area of the roost and lake was over $0.2 \mathrm{~kg}$ of $\mathrm{N}$ and nearly 1 $\mathrm{kg}$ of $\mathrm{P}$.

\section{Impact of great cormorants on soil fertility}

Soil analyses demonstrated the significant impact exerted by great cormorants on the terrestrial ecosystem beneath the roosting colony. Compared to the control, considerably increased concentrations of $\mathrm{N}$ forms and $\mathrm{P}$ were found in soils beneath the colony (Table 1). It is worth noting that the greatest impact of the colony of great cormorants on fertility was observed in the top soil layer. In the case of all investigated forms of $\mathrm{N}$ and $\mathrm{P}$, the concentrations found beneath the roost were statistically significantly higher compared to the control ( $\mathrm{T}$ test $\mathrm{p}<0.001)$. $\mathrm{N}_{\text {org }}$ dominated the $\mathrm{N}$ pool (almost $1000 \mathrm{mg} \mathrm{kg}^{-1}$ ), with $\mathrm{N}-\mathrm{NH}_{4}$ and $\mathrm{N}-\mathrm{NO}_{3}$ present in the surface layer in considerably lower concentrations, approximately $200 \mathrm{mg}$ $\mathrm{kg}^{-1}$ and $30 \mathrm{mg} \mathrm{kg}{ }^{-1}$, respectively. Significantly lower quantities of nutrients were found in deeper-lying soil layers (10-20 cm depth) under the colony. However, when compared with similar soil levels from control sites, the concentration of these chemical elements was always higher (Table 1). Statistically, concentrations of chemical elements in soil profiles located at sites beneath the colony differed significantly from those at the control stations. However, no statistically significant differences were found in the chemistry of any soil zone deeper than $20 \mathrm{~cm}$.
Impact of great cormorants on surface runoff chemistry

Surface runoff occurring on the forested catchment beneath the roosting colony contained a relatively high content of $\mathrm{N}$ and $\mathrm{P}$ and high electrical conductivity (Table 2). Compared to the site unaffected by great cormorants, the concentration of TP and total $\mathrm{N}$ in runoff under the roosting area was nearly 20-fold and over 50 -fold higher, respectively. $\mathrm{N}_{\text {org }}$ prevailed amongst the various $\mathrm{N}$ forms. Among the mineral forms, $\mathrm{N}-\mathrm{NH}_{4}$ was predominant (with mean content reaching nearly $400 \mathrm{mg} \mathrm{dm}^{-3}$ ), N-NO $\mathrm{NO}_{3}$ were present at a much lower level $\left(30 \mathrm{mg} \mathrm{dm}^{-3}\right)$ while $\mathrm{N}-\mathrm{NO}_{2}$ were found only in trace amounts (Table 2). The TRP represented more than $60 \%$ in the $\mathrm{P}$ pool.

The concentrations of the studied parameters were largely affected by the number of roosting great cormorants. The highest concentrations of all chemical elements were found in October 2011 when almost 250 birds were occupying the island.

For all the investigated parameters of surface runoff, a statistical significant difference between the roost area and control station was noted (Table 2).

\section{Impact of great cormorants on groundwater chemistry}

Within the area of the island (roosting colony), groundwater was found approximately $1 \mathrm{~m}$ below the surface. The groundwater table was similar to the level of the lake water. The chemical properties of shallow groundwater beneath the colony were different compared to the surface runoff. Concentrations of total $\mathrm{N}$ and total $\mathrm{P}$ were several times lower compared to those noted in runoff. Similarly, the content of soluble mineral salts in groundwater (manifested by electrical conductivity values) was almost four times lower (Table 3). Despite the relatively low content of the investigated chemical substances in groundwater, that found beneath the roosting colony was significantly more fertile compared to the groundwater observed at the control site, unaffected by birds (Table 3).

\section{Impact of great cormorants on lake water chemistry}

During the investigated period changes in the chemical properties of Lake Góreckie water were observed. The water collected from the littoral in close proximity to the colony revealed higher mean values of the investigated parameters compared to water collected 10 to $50 \mathrm{~m}$ from the edge and in the central part of the lake. Increased values of electrical conductivity and concentrations of $\mathrm{N}$ and $\mathrm{P}$ were found in the littoral zone located in close proximity to the roosting colony, especially in October 2011 (when the birds 
Table 1. Content of forms of nutrients in soils ( \pm Standard Error) beneath cormorant colony $(n=10)$

\begin{tabular}{|c|c|c|c|c|c|c|c|c|c|c|}
\hline \multirow{2}{*}{ layer } & \multicolumn{2}{|c|}{$\mathrm{N}-\mathrm{NH}_{4}\left[\mathrm{mg} \mathrm{kg}^{-1}\right]$} & \multicolumn{2}{|c|}{$\mathrm{N}-\mathrm{NO}_{3}\left[\mathrm{mg} \mathrm{kg}^{-1}\right]$} & \multicolumn{2}{|c|}{$\mathrm{N}$ organic $\left[\mathrm{mg} \mathrm{kg}^{-1}\right]$} & \multicolumn{2}{|c|}{$\mathrm{N}$ total $\left[\mathrm{mg} \mathrm{kg}^{-1}\right]$} & \multicolumn{2}{|c|}{$\mathrm{P}$ total $\left[\mathrm{mg} \mathrm{kg}^{-1}\right]$} \\
\hline & colony & control & colony & control & colony & control & colony & control & colony & control \\
\hline Organic & $\begin{array}{r}197.7 \\
\pm 16.1 \\
\end{array}$ & $\begin{array}{l}51.1 \\
\pm 7.8 \\
\end{array}$ & $\begin{array}{l}30.89 \\
\pm 4.03 \\
\end{array}$ & $\begin{array}{c}12.3 \\
\pm 1.08 \\
\end{array}$ & $\begin{array}{l}974.2 \\
\pm 91.9 \\
\end{array}$ & $\begin{array}{c}211.3 \\
\pm 31.21 \\
\end{array}$ & $\begin{array}{c}1205.5 \\
\pm 72.1 \\
\end{array}$ & $\begin{array}{l}294.1 \\
\pm 10.9 \\
\end{array}$ & $\begin{array}{c}1276.4 \\
\pm 122.82 \\
\end{array}$ & $\begin{array}{r}67.2 \\
\pm 4.49 \\
\end{array}$ \\
\hline Minero-organic & $\begin{array}{l}87.1 \\
\pm 4.8 \\
\end{array}$ & $\begin{array}{c}43.6 \\
\pm 4.08 \\
\end{array}$ & $\begin{array}{c}9.64 \\
\pm 0.88\end{array}$ & $\begin{array}{c}7.51 \\
\pm 0.71\end{array}$ & $\begin{array}{c}193.2 \\
\pm 19.19\end{array}$ & $\begin{array}{c}87.4 \\
\pm 15.62\end{array}$ & $\begin{array}{l}289.3 \\
\pm 10.5\end{array}$ & $\begin{array}{c}138.2 \\
\pm 6.2\end{array}$ & $\begin{array}{c}155.5 \\
\pm 14.22\end{array}$ & $\begin{array}{c}24.2 \\
\pm 11.69\end{array}$ \\
\hline Mineral & $\begin{array}{l}38.5 \\
\pm 3.8 \\
\end{array}$ & $\begin{array}{c}32.2 \\
\pm 1.93 \\
\end{array}$ & $\begin{array}{c}5.7 \\
\pm 0.64\end{array}$ & $\begin{array}{c}3.9 \\
\pm 0.37\end{array}$ & $\begin{array}{c}37.2 \\
\pm 2.08\end{array}$ & $\begin{array}{c}25.9 \\
\pm 1.32\end{array}$ & $\begin{array}{l}81.2 \\
\pm 3.7\end{array}$ & $\begin{array}{l}62.4 \\
\pm 2.2\end{array}$ & $\begin{array}{l}25.4 \\
\pm 2.8\end{array}$ & $\begin{array}{c}20.4 \\
\pm 1.71\end{array}$ \\
\hline
\end{tabular}

Table 2. Physical and chemical properties of surface runoff water beneath cormorant roosting colony and at control station ( $\mathrm{n}=10)$

\begin{tabular}{|c|c|c|c|c|c|c|c|}
\hline & & & Mean & Min & Max & SD & Mann Whitney U test \\
\hline \multirow{2}{*}{$\mathrm{N}-\mathrm{NH}_{4}$} & colony & \multirow{2}{*}{$\mathrm{mgN} \mathrm{dm}{ }^{-3}$} & 137.4 & 33 & 475 & 122.6 & $Z=3.74$ \\
\hline & control & & 2.2 & 0.6 & 3.5 & 0.7 & $p<0.001$ \\
\hline \multirow{2}{*}{$\mathrm{N}-\mathrm{NO}_{3}$} & colony & \multirow{2}{*}{$\mathrm{mgN} \mathrm{dm}^{-3}$} & 26.1 & 9.1 & 55 & 13.2 & $Z=3.74$ \\
\hline & control & & 1.5 & 0.5 & 2.4 & 0.59 & $p<0.001$ \\
\hline \multirow{2}{*}{$\mathrm{N}-\mathrm{NO}_{2}$} & colony & \multirow{2}{*}{$\mathrm{mgN} \mathrm{dm}^{-3}$} & 0.35 & 0.02 & 0.9 & 0.29 & $Z=3.77$ \\
\hline & control & & 0.001 & 0 & 0.004 & 0.002 & $p<0.001$ \\
\hline \multirow{2}{*}{$\mathrm{N}$ org. } & colony & \multirow{2}{*}{$\mathrm{mgN} \mathrm{dm}^{-3}$} & 379.1 & 68 & 610 & 197 & $Z=3.74$ \\
\hline & control & & 4.3 & 2.2 & 11 & 2.5 & $p<0.001$ \\
\hline \multirow{2}{*}{$\mathrm{N}$ tot. } & colony & \multirow{2}{*}{$\mathrm{mgN} \mathrm{dm}^{-3}$} & 542.9 & 202.6 & 1021 & 260.5 & $Z=3.74$ \\
\hline & control & & 8.1 & 5.4 & 15.5 & 3.2 & $p<0.001$ \\
\hline \multirow{2}{*}{$P$ tot. } & colony & \multirow{2}{*}{$\mathrm{mgP} \mathrm{dm}^{-3}$} & 9.7 & 3.2 & 17.2 & 4.3 & $Z=3.74$ \\
\hline & control & & 0.4 & 0.09 & 1.1 & 0.3 & $p<0.001$ \\
\hline \multirow{2}{*}{ TRP } & colony & \multirow{2}{*}{$\mathrm{mgP} \mathrm{dm}^{-3}$} & 6.2 & 1.1 & 11.1 & 3.1 & $Z=3.75$ \\
\hline & control & & 0.11 & 0.006 & 0.25 & 0.07 & $p<0.001$ \\
\hline \multirow{2}{*}{$\mathrm{pH}$} & colony & & 5.8 & 5.3 & 6.5 & 0.41 & $Z=2.63$ \\
\hline & control & & 4.8 & 3.52 & 6.2 & 0.9 & $p<0.05$ \\
\hline \multirow{2}{*}{ Cond. } & colony & \multirow{2}{*}{$\mu S \mathrm{~cm}^{-1}$} & 2971 & 1020 & 6100 & 1458.4 & $Z=3.74$ \\
\hline & control & & 107.3 & 72 & 185 & 33.4 & $p<0.001$ \\
\hline
\end{tabular}

Table 3. Physical and chemical properties of ground water beneath cormorant roosting colony and at control station ( $\mathrm{n}=10)$

\begin{tabular}{|c|c|c|c|c|c|c|c|}
\hline & & & Mean & Max & Min & SD & Mann Whitney U test \\
\hline \multirow{2}{*}{$\mathrm{N}-\mathrm{NH}_{4}$} & colony & \multirow{2}{*}{$\mathrm{mgN} \mathrm{dm}^{-3}$} & 4.19 & 9.2 & 2.4 & 2.12 & $Z=3.84$ \\
\hline & control & & 1.51 & 2.3 & 0.7 & 0.48 & $p<0.001$ \\
\hline \multirow{2}{*}{$\mathrm{N}-\mathrm{NO}_{3}$} & colony & \multirow{2}{*}{$\mathrm{mgN} \mathrm{dm}^{-3}$} & 2.31 & 4.6 & 0.9 & 0.99 & $Z=3.48$ \\
\hline & control & & 0.7 & 1.7 & 0.2 & 0.45 & $p<0.001$ \\
\hline \multirow{2}{*}{$\mathrm{N}-\mathrm{NO}_{2}$} & colony & \multirow{2}{*}{$\mathrm{mgN} \mathrm{dm}^{-3}$} & 0.01 & 0.04 & 0 & 0.01 & $Z=1.22$ \\
\hline & control & & 0.008 & 0.04 & 0 & 0.01 & $p>0.05$ \\
\hline \multirow{2}{*}{ N org. } & colony & \multirow{2}{*}{$\mathrm{mgN} \mathrm{dm}{ }^{-3}$} & 7.18 & 12.4 & 3.1 & 2.9 & $Z=3.84$ \\
\hline & control & & 1.92 & 2.9 & 0.9 & 0.55 & $p<0.001$ \\
\hline \multirow{2}{*}{$\mathrm{N}$ tot. } & colony & \multirow{2}{*}{$\mathrm{mgN} \mathrm{dm}^{-3}$} & 13.7 & 25 & 7.9 & 4.9 & $Z=3.83$ \\
\hline & control & & 4.1 & 5.2 & 2.3 & 0.9 & $p<0.001$ \\
\hline \multirow{2}{*}{ P tot. } & colony & \multirow{2}{*}{$\mathrm{mgP} \mathrm{dm}^{-3}$} & 0.84 & 1.9 & 0.25 & 0.48 & $Z=3.76$ \\
\hline & control & & 0.17 & 0.26 & 0.1 & 0.05 & $p<0.001$ \\
\hline \multirow{2}{*}{ TRP } & colony & \multirow{2}{*}{$\mathrm{mgP} \mathrm{dm}^{-3}$} & 0.42 & 0.8 & 0.1 & 0.25 & $Z=3.79$ \\
\hline & control & & 0.08 & 0.1 & 0.06 & 0.01 & $p<0.001$ \\
\hline \multirow{2}{*}{$\mathrm{pH}$} & colony & & - & 7.1 & 5.8 & 0.38 & $Z=0.035$ \\
\hline & control & & - & 6.9 & 6.2 & 0.25 & $p>0.05$ \\
\hline \multirow{2}{*}{ Cond. } & colony & \multirow{2}{*}{$\mu \mathrm{S} \mathrm{cm} \mathrm{cm}^{-1}$} & 805.9 & 1124 & 650 & 126.3 & $Z=3.83$ \\
\hline & control & & 191.2 & 261 & 93 & 56.9 & $p<0.001$ \\
\hline
\end{tabular}


were most abundant). During this month, the mean concentration of TP was 20 times higher (2.1 vs 0.11 $\mathrm{mg} \mathrm{dm}^{-3}$ ) compared to the pelagic zone. TRP concentration reached $1.01 \mathrm{mg} \mathrm{dm}^{-3}$ in the littoral zone while in other parts of the lake ( 10 and $50 \mathrm{~m}$ from the colony), it was found only in trace concentrations. At the same time, the concentration of the mineral $\mathrm{N}$ in the littoral zone near the colony was three-fold higher (3.1 vs. $0.9 \mathrm{mg} \mathrm{dm}^{-3}$ ) while $\mathrm{N}_{\text {org }}$ was four times higher ( 8.1 vs. $1.98 \mathrm{mg} \mathrm{dm}^{-3}$ ) than in the pelagial. Electrical conductivity of the littoral zone near the colony was twice as high $\left(990 \mu \mathrm{S} \mathrm{cm}^{-1}\right)$ as that noted in the pelagic zone. However, when the entire investigated period was analysed, significant differences between sampling sites were only found for electrical conductivity (ANOVA Kruskal Wallis $\mathrm{H}=10.23 \mathrm{p}<0.05$ ) while for the other studied parameters the median values were similar (Fig. 2).

\section{Discussion}

Great cormorants gather at roosts, both during the day and at night. After foraging they tend to form day roosts, close to their feeding areas. Usually, day roosts contain only a few dozen birds but some may be used by hundreds of individuals (Bregnballe et al. 2012). Cormorants have a rapid metabolism, therefore they are responsible for the turnover of matter and energy in and between ecosystems (Mukherejee and Board 2001). They produce significant amounts of faeces that may influence geochemical cycles, both on land and in water (Gwiazda et al. 2010). Roosting cormorants can deliver significant loads of nutrients with their droppings, directly into the lake or onto land in the proximity of the lake, and accelerate eutrophication of freshwater (Kameda et al. 2000; Goc et al. 2005; Andrikovics et al. 2006). McCann et al. (1997) calculated that a roosting colony of great cormorants supplies Lake Aldair - a small and shallow reservoir - with 70 $\%$ and $36 \%$ of its total $\mathrm{P}$ and $\mathrm{N}$ content, respectively. Removal of the birds and the elimination of the great cormorant colony led to an increase in lake water quality (McCann et al. 2000). Our calculations suggested that the daily load of nutrients delivered by cormorants to Lake Góreckie (at maximal colony abundance) in the case of $\mathrm{P}$ is equal to the load of $\mathrm{P}$ inflowing from other sources from the entire catchment area. In the case of $\mathrm{N}$, great cormorants deliver only $1 \%$ of the total load. The estimations of the $\mathrm{N}$ load delivered by birds were given according to Marion et al. (1994), who calculated
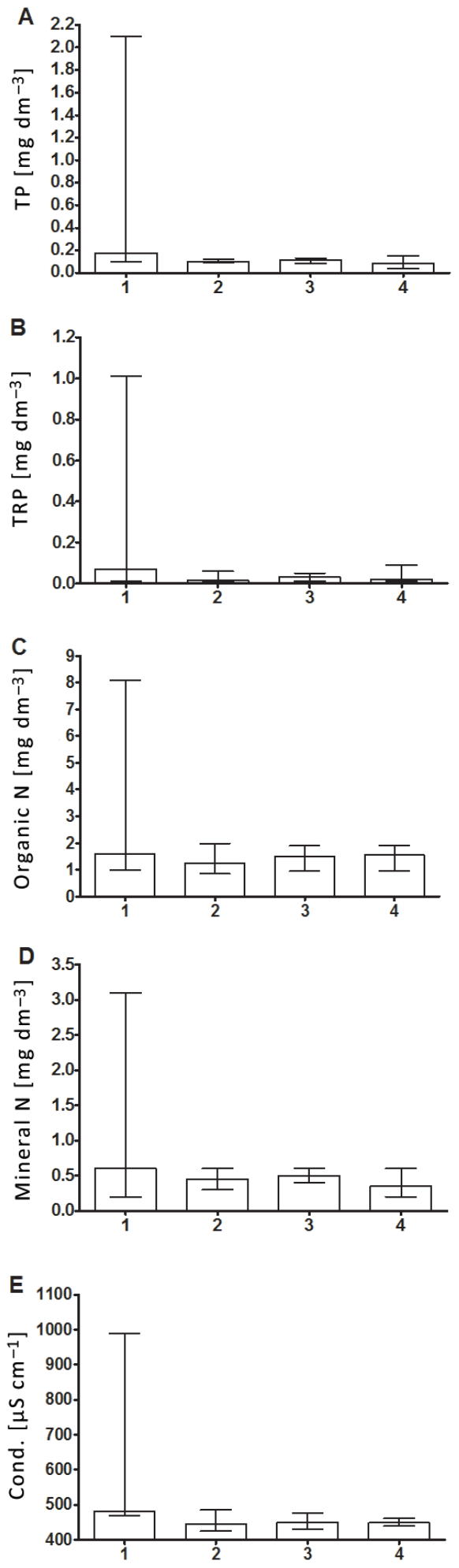

Fig. 2. Median (box) and range (whisker) of TP (A), TRP (B), Nmin. (C), Norg. (D) and electrical conductivity (E) of the surface water in transect: 1 - at edge of the colony, $2-10 \mathrm{~m}$ from the colony, $3-50 \mathrm{~m}$ from the colony, 4 - central part of the lake 
that $\mathrm{N}$ constitutes about $3.3 \%$ of dry mass of droppings. Other studies show, however, that the content of $\mathrm{N}$ in great cormorant faeces can be equal to the content of $\mathrm{P}$ and exceed 10\% (Kameda et al. 2000; Goc et al. 2005; Gwiazda et al. 2010). A significant quantity of droppings is delivered directly into the water because Cormorants prefer to gather on the edge part of the island, and occupy tree branches over the water table. Some loads are also delivered onto the land.

Loads of $\mathrm{N}$ and $\mathrm{P}$ found in the top soil layer beneath the great cormorant roost at Lake Góreckie are only slightly lower than those noted in soils under perennial colonies (Ligęza and Smal 2003; Hobara et al. 2005). It is highly plausible that the large quantities of nutrients observed in soils beneath a developing roosting colony are brought about by the greater density of great cormorants in comparison to perennial nesting colonies. Compared to other colonies (Ligęza et al. 2001; Hobara et al. 2001, 2005), the deeper soil layers under the roosting colony at Lake Góreckie contain smaller quantities of $\mathrm{N}$ and P. The impact of the great cormorants on soil chemistry is only traceable to the depth of $20 \mathrm{~cm}$.

The results of our work demonstrate that nutrients and other chemical elements deposited within the area of the colony are easily transferred into the neighbouring lake and only partially find their way to the soil. The main path of transfer of chemicals from the area of the roost to the lake is surface runoff. Some literature data suggested that the transfer of $\mathrm{N}$ and $\mathrm{P}$ from soils under great cormorant colonies into groundwater is minimal. In forest pressured by cormorants, volatilization of ammonia into the atmosphere is predominant whereas $\mathrm{P}$ is effectively accumulated in soils (Mulder and Keall 2001; Hobara et al. 2005; Osono et al. 2006). We found that surface runoff promotes the elution of $\mathrm{N}, \mathrm{P}$ and other chemicals from soils beneath the colony. The concentration of $\mathrm{N}$ and $\mathrm{P}$ noted in surface runoff occurring in the area colonized by birds was significantly higher compared to the control, as well as to those concentrations observed in other natural ecosystems (Klimaszyk and Rzymski 2011; 2013b).

Despite the fact that the groundwater table beneath the colony is at an insignificant depth below the ground surface (approximately $0.7 \mathrm{~m}$ ), the penetration of nutrients of bird origin is limited. Compared to surface runoff, concentrations of all chemical elements in groundwater were significantly lower. In turn, this suggests that loads of nutrients delivered by great cormorants are mainly accumulated in the top layer of soils or washed out by surface runoff. This is due to the short duration of the colony and relatively low loads deposited by birds. At perennial great cormorant colonies ground waters are usually much more fertile (Klimaszyk 2012).

Lake water chemistry was demonstrated to be significantly affected only during the time the birds were most abundant (October 2011). These differences, demonstrated by increased nutrient concentrations and electrical conductivity, were only found for the zone narrower than $10 \mathrm{~m}$ from the colony. Intensive water circulation in the lake (caused by wave motion) promotes the dilution of nutrient loads delivered by birds. Moreover, $\mathrm{N}$ and P, particularly in the inorganic form, can be easily and rapidly utilized by phytoplankton. As shown, during summer stratification, the epilimnion of Lake Góreckie is characterized by a high rate of primary production and an abundance of filamentous cyanobacteria (Szeląg-Wasielewska and Fyda 2006). This results in decreased water transparency and limited growth of submerged macrophytes. It has already been shown that a colony of great cormorants can induce significant biological changes in lakes and decrease the abundance of macrophyte species, particularly those susceptible to nutrient enrichments (Klimaszyk et al. 2014). As can be postulated from the present study, the roosting colony of great cormorants represents one of the important sources of eutrophication-inducing factors for the studied lake.

\section{Conclusions}

Our study demonstrates that the roosting colony of great cormorants can significantly affect the chemistry of the lake. The birds that gather at roosts deposit considerable loads of nutrients and other chemical elements on the land ecosystem beneath the colony. As found, some of this load accumulates in soils and pollutes them while the remainder is transported with surface runoff and groundwater into the neighbouring lake ecosystem. Even in the case of small roosts, the loads of chemical elements (particularly P) delivered by birds are comparable to those from the natural catchment area and may accelerate the eutrophication of freshwater. Therefore, great cormorants may play a significant role in chemical and biological changes in surface waters, particularly if one considers the observed increase in the population growth of these birds in many world regions. 


\section{Acknowledgements}

The research was supported by a grant from the Polish Ministry of Science No. NN305100435. The authors would also like to thank Mr Rob Kippen for the proofreading.

\section{References}

Andrikovics S., Gere G., Juhasz J., Lakatos G., 2006, Mallard waste production and effects on water bodies, [in:] Hanson A.. Kerekes J., Paquet J., (eds.), Limnology and Aquatic Birds: Abstracts and selected papers from the Fourth Conference of the Societas Internationalis Limnologiae (SIL) Aquatic Birds Working Group, Canadian Wildlife Service Technical Report No 474: 125-130.

[APHA] American Public Health Association, 2005, Standard methods for the examination of water and waste water, APHA-AWWA-WEF, New York.

Bregnballe T., Carss D.N., Lorentsen S.-H., Newson S., Paquet J.Y., Parz-Gollner R., Volponi S., 2012, Counting cormorants, [in:] Carss D., Parz-Gollner R., Trauttmansdorff J., (eds), The INTERCAFE Field Manual: Research methods for cormorants, fishes, and the interactions between them, INTERCAFE COST Action 635 Final Report II: $14-34$.

Bzoma S., Goc M., Brylski T., Stempniewicz L., Iliszko L., 2003, Seasonal changes and intracolony differentiation in the exploitation of two feeding grounds by Great Cormorants (Phalacrocorax carbo sinesis) breeding at Kąty Rybackie (N Poland), Vogelwelt 124: 175-181.

Cramp S., Simmons K.E.L., 1977, The birds of the Western Palearctic: Vol. 1, Oxford University Press, Oxford-New York: p. 722.

Gere G., Andrikovics S., 1992, Effects of waterfowl on water quality, Hydrobiologia 243-244: 445-448.

Goc M., Iliszko L., Stempniewicz L., 2005, The largest European colony of the Great cormorant on the Vistula Spit - an impact of the forest ecosystem, Ecol. Quest. 6: 93-103.

Gwiazda R., Jarocha K., Szarek-Gwiazda E., 2010, Impact of small Cormorant (Phalacrocorax carbo sinensis) roost on nutrients and phytoplankton assemblages in the littoral regions of submontane reservoir, Biologia 65(4): 742-748.

Hobara S., Koba K., Osono T., Tokuchi N., Ishida A., Kameda K., 2005, Nitrogen and phosphorus enrichment and balance in forest colonized by cormorants: Implications of the influence of soil adsorption, Plant Soil 268(1): 89101.

Hobara S., Osono T., Koba K., Tokuchi N., Fujiwara S., Kameda K., 2001, Forest floor quality and $\mathrm{N}$ transformations in a temperate forest affected by avian-derived $\mathrm{N}$ deposition, Water Air Soil Poll. 130: 679-684.
Kameda K., Koba K., Yosimizu C., Fujiwara S., Hobara S., Koyama R., Tokuchi N., Takayagi A., 2000, Nutrient flux from aquatic to terrestrial ecosystem maintained by the great cormorant, Sylvia 36: 54-55.

Kameda K., Koba K., Hobara S., Osono T., Terai M., 2006, Pattern of natural $15 \mathrm{~N}$ abundance in lakeside forest ecosystem affected by cormorant-derived nitrogen, Hydrobiologia 567: 69-86.

Klimaszyk P., 2012, May a cormorant colony be a source of coliform and chemical pollution in a lake?, Oceanol. Hydrobiol. Stud. 41(1): 67-73.

Klimaszyk P., Rzymski P., 2011, Surface runoff as a factor determining trophic state of midforest lake (Piaseczno Małe, North Poland), Pol. J. Environ. Stud. 5: 1203-1210.

Klimaszyk P., Rzymski P., 2013a, Impact of cormorant (Phalacrocorax carbo sinensis $\mathrm{L}$.) colonies on microbial pollution in lakes, Limnol. Rev. 13(3): 139-145.

Klimaszyk P., Rzymski P., 2013b, Catchment vegetation can trigger lake dystrophy through changes in runoff water quality, Ann. Limnol., Int. J. Limnol. 49(3): 191-197.

Klimaszyk P., Piotrowicz R., Rzymski P., 2014, Changes in the ecosystem of shallow softwater lake induced by the Great Cormorant roosting colony, J. Limnol. doi: 10.4081/jlimnol.2014.994

Ligęza S., Smal H., 2003, Accumulation of nutrients in soils affected by perennial colonies of piscivorous birds with reference to biogeochemical cycles of elements, Chemosphere 52(3): 595-602.

Ligęza S., Smal H., Misztal M., Ciesielczuk P., Piliszczuk G., 2001, Zmiany wybranych właściwości środowiska glebowego na terenie kolonii kormoranów (Phalacrocorax carbo) w Kątach Rybackich (Changes in selected soil properties on the area of a cormorant (Phalacrocorax carbo) colony in Kąty Rybackie), Acta Agrophys. 56: 155-164 (in Polish).

Marion L., Clergeau P., Brient L., Bertu G., 1994, The importance of avian-contributed nitrogen $(\mathrm{N})$ and phosphorus (P) to Lake Grand-Lieu, France, Hydrobiologia 279/280: 133-147.

McCann K.D., Olson L.D., Hardy P.G., 1997, Contribution of roosting cormorants to the nutrient budget of Lake Aldair (Ontario, Floryda), Proc. of the Florida Lake Management Society, Palm Beach: 89-90.

McCann K.D., Olson L.D., Hardy P.G., 2000, Water quality in Lake Adair following removal of roosting cormorants, Proceedings of the Florida Lake Management Society. 2000 Annual Conference, Duck Key: 54-55.

Mukherjee A., Borad C.K., 2001, Effect of waterbirds on water quality, Hydrobiologia 464: 201-205.

Mulder C.P.H., Keall S.N., 2001, Burrowing seabirds and reptiles: impact on seeds and soils in an island forest in New Zealand, Oecologia 127(3): 350-360.

Nakamura M., Yabe T., Ishii Y., Kido K., Aizaki M., 2010, Extreme eutrophication in a small pond adjacent to a forest colonized by great cormorant (Phalacrocorax carbo), Jpn. J. Limnol. 71:19-26. 
Osono T., Hobara S., Koba K., Kameda K., Takeda H., 2006, Immobilization of avian excreta-derived nutrients and reduced lignin decomposition in needle and twig litter in a temperate coniferous forest, Soil Biol. Biochem. 38(3): 517-525.

Prince A.L., 1995, Appendix - Methods in soil analysis, [in:] Bear F.E. (ed.), Chemistry of Soil, ACS Monograph No 126, Reinhold Publishing Corporation, New York: 328362.

Saks L., 2012, Sytuacja kormorana w Estonii: Zmiany liczebności populacji i interakcje z rybołowstwem (Cormorants in Estonia: changes in population abundance), [in:] Kormoran w aspekcie zrównoważonego korzystania $\mathrm{z}$ zasobów rybackich (Cormorants with regard to the sustainable use of fish resources), MIR-PIB, Gdynia: 50-59 (in Polish).

Sobczyński T., Joniak T., 2009, Vertical changeability of physical-chemical features of bottom sediments in three lakes, in aspect type of water mixis and intensity of human impact, Pol. J. Environ. Stud. 18(6): 1093-1099.

Sobczyński T., Joniak T., 2013, The variability and stability of water chemistry in a deep temperate lake: results of long-term study of eutrophication, Pol. J. Environ. Stud. 22(1): 227-237.
Szeląg-Wasielewska E., Fyda J., 2006, Pelagic biocoenosis in a stratified eutrophic lake: vertical variation in the microbial loop and phytoplankton, Limnol. Rev. 6: 269-276.

Szyper H., Gołdyn R., 2002, Role of catchment area in the transport of nutrients to lakes in the Wielkopolska National Park in Poland, Lakes Reserv. Res. Manage. 7(1): 25-33.

van Eerden M.R., Gregersen J., 1995, Long-term changes in the northwest European populations of Cormorants Phalacrocorax carbo sinensis, Ardea 83: 61-79.

van Eerden M.R., van Rijn S., Volponi S., Paquet J.Y., Carss D., 2012, Cormorants and the European Environment; exploring cormorant status and distribution on a continental scale. INTERCAFE COST Action 635 Final Report I. NERC Centre for Ecology \& Hydrology: p. 129.

van Reeuwiijk L.P, 2002, Procedures of soil analysis. ISRIC: p. 119.

White C.R., Boertmann D., Gremillet D., Butler P.J., Green J.A., Martin G.R., 2011, The relationship between sea surface temperature and population growth of Great Cormorants near Disco Bay, Greenland, Ibis 153: 170-174. 